\title{
Vegetation of the Witbank Nature Reserve and its importance for conservation of threatened Rocky Highveld Grassland
}

\section{C.M. SMIT, G.J. BREDENKAMP. N. VAN ROOYEN, A.E. VAN WYK and J.M. COMBRINCK}

Smit, C.M., G.J. Bredenkamp, N. van Rooyen, A.E. van Wyk and J.M. Combrinck. 1997. Vegetation of the Witbank Nature Reserve and its importance for conservation of threatened Rocky Highveid Grassland. Koedoe 40(2): 85-104. Pretoria. ISSN $0075-6458$.

\begin{abstract}
A vegetation survey of the Witbank Nature Reserve, comprising 847 hectares, was conducted. Phytosociological data were used to identify plant communities, as well as to determine alpha and beta diversities. Eleven plant communities were recognised, two of these are subdivided into sub-communities, resulting in 14 vegetation units. These communities represent four main vegetation types, namely grassland, woodland, wetland and disturbed vegetation. Grassland communities have the highest plant diversity and wetland vegetation the lowest. Floristic composition indicates that the vegetation of the Rocky Highveld Grassland has affinities to the grassland and savanna biomes and also to the Afromontane vegetation of the Great Escarpment. An ordination scatter diagram shows the distribution of the 14 plant communities or sub-communities along a soil moisture gradient, as well as along a soil depth/surface rock gradient. The sequence of communities along the soil moisture gradient is used for calculating beta-diversity indices. It is concluded that the relatively small size of the Witbank Nature Reserve is unlikely to have significant negative effects on the phytodiversity of the various plant communities. This nature reserve is therefore of considerable importance in conserving a representative sample of the Rocky Highveld Grassland.
\end{abstract}

Key words: plant communities, conservation area, Rocky Highveld Grassland. BraunBlanquet, biodiversity, small area, habitat size, transitional zones.

C.M. Smit, SAFCOL, Private Bag X506, Eshowe, 3815 Republic of South Africa; G.J. Bredenkamp, N. van Rooven and A.E. Van Wyk, Department of Botany: University of Pretoria, Pretoria, 0002 Republic of South Africa; J.M. Combrinck, Witbank Nature Reserve, PO Box 3, Witbank, 1035 Republic of South Africa.

\section{Introduction}

In South Africa it was hitherto common practice to proclaim nature reserves around artificially created water bodies, mostly with the primary objective of securing the dam wall and associated construction and engineering works, and for public recreation. Conservation areas should, however, be proclaimed to protect representative examples of specific vegetation types, as well as rare, endangered, threatened and endemic plant and animal species within their natural habitats. In proclaiming the Witbank Nature Reserve (WNR) around a part of the Witbank Dam, the responsible authority coincidentally managed to conserve an area with exceptionally high plant diversity. In this relatively small area of approximately 847 ha, about 400 plant species were collected during the present study. Although the WNR is included in the Moist Sandy Highveld Grassland (Vegetation Type 38) (Low \& Rebelo 1996), the reserve is situated in a transitional zone and mostly represents an unmapped island of Rocky Highveld Grassland (Vegetation Type 34) along the Olifants River Valley, with oniy small patches of typical Moist Sandy Highveld Grassland present.

The floristically diverse Rocky Highveld Grassland is considered as highly threatened by agriculture, urbanisation, industrialisation and mining, and of the original $24063 \mathrm{~km}^{2}$ of this vegetation type, an estimated $65 \%$ has already been transformed, where-as only 


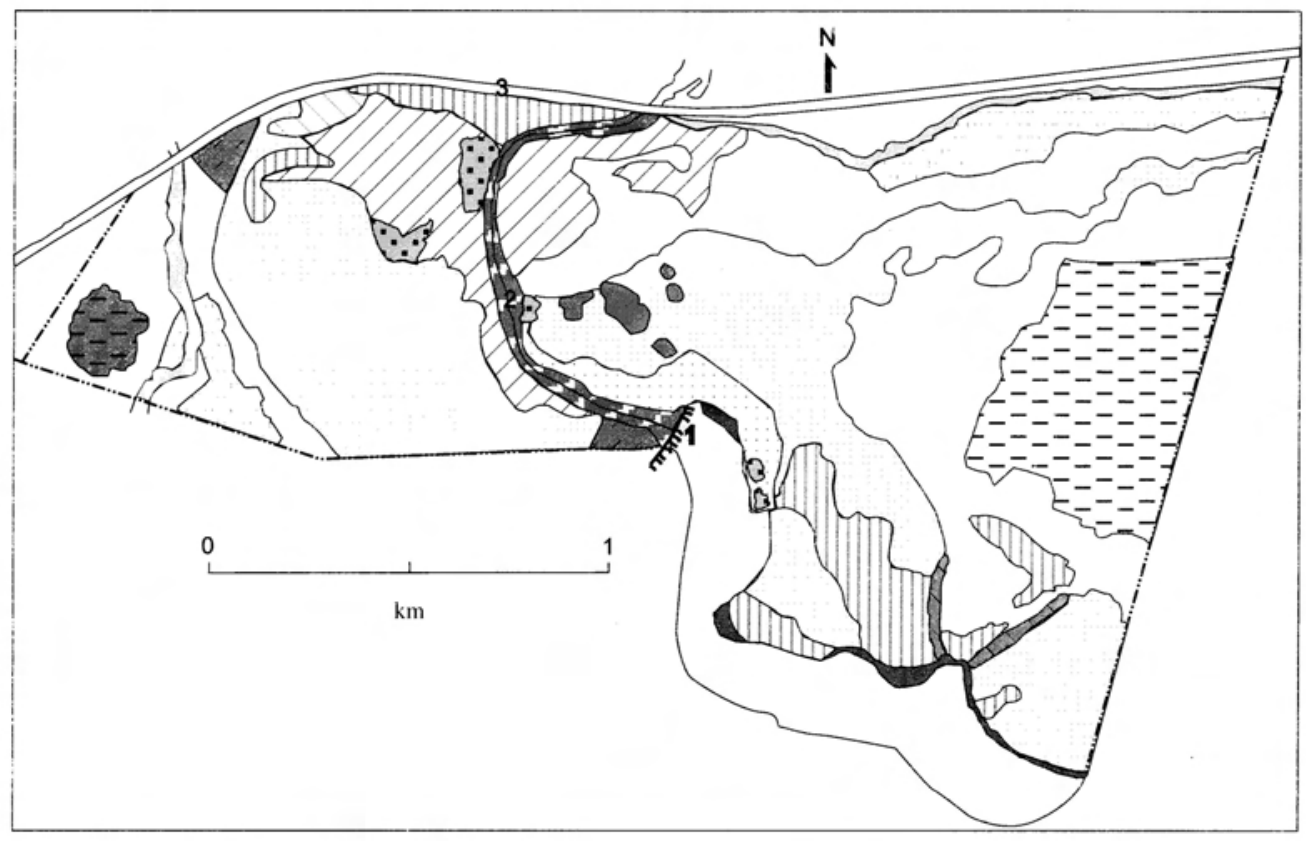

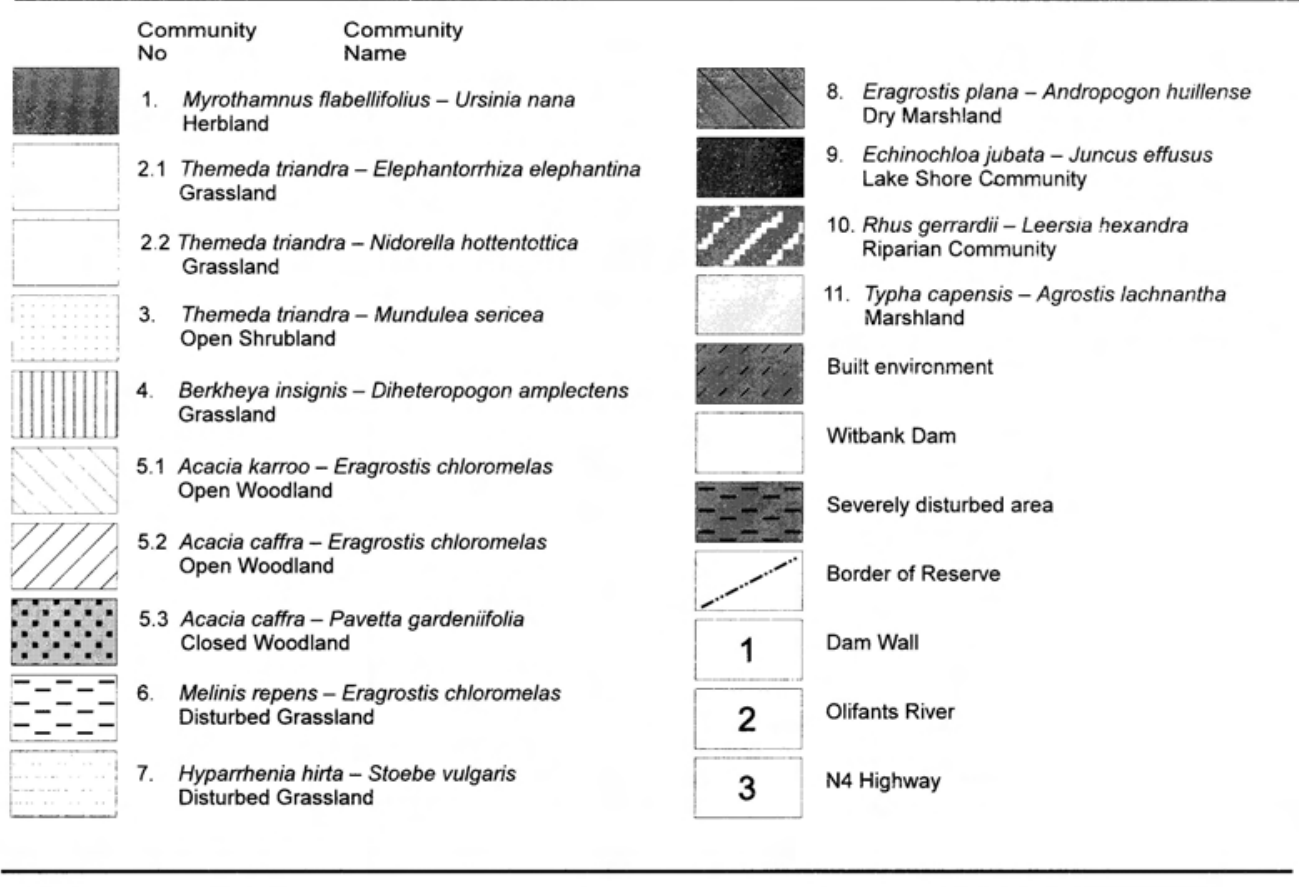

Fig. 1. Vegetation map of the Witbank Nature Reserve. 
$1.38 \%$ of this area is officially conserved (Bredenkamp \& Van Rooyen 1996). The Witbank area is severely disturbed as a resuit of extensive coal mining activities. Natural areas not destroyed by opencast mining, are generally used for cultivation of maize or other crops, especially in the Moist Sandy Highveld Grassland in the near vicinity of the Witbank Nature Reserve. Large areas are invaded by alien plants, such as Acacia mearnsii, and the remaining natural areas used for grazing are often over-utilised and invaded by pioneer dwarf shrubs, notably Stoebe vulgaris. Pollution of the upper Olifants River is an issue widely discussed by conservationists. An Olifants River Forum has been formed by private initiative in order to investigate this problem.

Considering the above, the role of small nature reserves as conservation areas, such as the WNR, becomes significant in conserving parts of the phytodiversity of this endangered vegetation type. The aims of this study are to classify the vegetation, identify the plant communities, interpret these in terms of habitat and to assess the diversity of the vegetation of the reserve. Comment is also provided on the viability of small nature reserves in this part of the Grassland Biome.

\section{The study area}

The WNR is situated in the Mpumalanga Province, South Africa, directly east of the town of Witbank, hugging the northern outlet of the Witbank Dam. This reservior was built in the Olifants River (Fig. 1), with a catchment area of approximately $3540 \mathrm{~km}^{2}$. The first wall was completed in 1951, then raised to $40 \mathrm{~m}$ in 1972 . The WNR was proclaimed on 1 April 1979 and covers an area of approximately 847 hectares. It is situated at an altitude of 1 450-1 $500 \mathrm{~m}$, in undulating country, which is representative of Bankenveld (Acocks 1988) or Rocky Highveld Grassland (Bredenkamp \& Van Rooyen 1996). This vegetation type is exceptionally rich in plant species, particularly forbs, with floristic elements from the
Grassland and Savanna Biomes, as well as the Afromontane (Drakensberg) region (Bredenkamp \& Van Rooyen 1996). Acocks (1988) interprets Bankenveld as a fire-maintained False Grassland, which would develop into savanna if fire was excluded. However, Bredenkamp \& Van Rooyen (1996) maintain that climate, especially frost during winter, plays the key role in the distribution of woody vegetation in this vegetation type. Woodland is restricted to sheltered sites while the predominant grassland occurs on exposed crests and plains. This region comprises a transitional escarpment landscape between high-altitude temperate grassland and warmer bushveld at lower altitudes.

The rocky stream bed of the Olifants River divides the WNR into western and eastern parts (Fig. 1). Part of the river runs through a narrow, steep-sloped valley with sheltered habitats, suitable for woodland vegetation and typical of Rocky Highveld Grassland.

According to the Land Type Survey Staff (1987), the entire WNR is situated in the Fa8 land type.

The predominant rock formations consist of rhyolitic lava of the Selons River Formation, Rooiberg Group, Bushveld Igneous Complex (Land Type Survey Staff 1987), also referred to as felsite, as well as intrusive diabase rocks (Rand Mines 1992). Alluvium consisting of silt, sand and gravel was deposited by the river over the older rocks in the valleys (Rand Mines 1992).

Soils of the WNR are predominantly rocky and shallow, which explains why so little of the area was subjected to cultivation, and why the area is representative of Rocky Highveld Grassland rather than Moist Sandy Highveld Grassland. Soil depth of the predominant Glenrosa and Mispah soil forms (Grondklassifikasiewerkgroep 1991) is only 100-300 mm. Occasional deeper soils, $450-600 \mathrm{~mm}$ deep, are representative of the Clovelly and Hutton soil forms, typical of Moist Sandy Highveid Grassland, and these were mostly ploughed in the past. 
The area is situated in a summer rainfall area, with moderate to hot summers and moderately cold winters. Frost occurs from May to September. Mean annual precipitation is $709 \mathrm{~mm}$ and the mean annual temperature is $15^{\circ} \mathrm{C}$. December and January are the hottest months (mean daily maximum = $27^{\circ} \mathrm{C}$ ) and June and July the coldest (mean daily minimum $=-1.8^{\circ} \mathrm{C}$ ).

\section{Methods}

\section{Sampling}

Sampling was done in 43 stratified random plots. Stratification units were determined from aerial photographs. These units represent relatively homogeneous vegetation and habitat types. Plot sizes were fixed at $10 \times 10 \mathrm{~m}$ for grassland vegetation (Bredenkamp \& Theron 1978) and at $10 \times 20 \mathrm{~m}$ for woodland (Bredenkamp 1982). The number of sample plots per stratification unit depended on the size of each unit. Total floristic composition was recorded in each plot, using the Braun-Blanquet coverabundance scale (Westhoff \& Van der Maarel 1982). Environmental factors such as soil type and depth, clay content, geology, percentage surface rccks, slope and aspect, as well as degree of erosion and veld degradation were recorded. Vegetation structure was classified according to Edwards (1983), and where appropriate, reflected in the names of the plant communities. Names of taxa follow Arnold \& De Wet (1993). Plant life forms according to Raunkiaer, as revised by Miueller-Dombois \& Ellenberg (1974), are indicated next to species names in the phytosociological table (Table 1).

\section{Data processing}

Classification of relevès, based on the floristic data, was done by Two-way Indicator Species Analysis (TWINSPAN) (Hill 1979a). Results of this analysis were considered as a first approximation of the vegetation types of the area, and were further refined by using Braun-Blanquet procedures (Westhoff \& Van der Maarel 1982; Beł:: \&: D.edenkamp 1988), is produce a final phytosociological table. Data were subjected to ordination to identify possible gradients between and within the recognised plant communities, and to relate community variation to environmental gradients. Detrended Correspondence Analysis (DECORANA) (Hill 1979b) was used to produce a scatter diagram of synoptic relevès (plant communities).
Alpha diversity (species richness) is defined as the number of species per unit area within a homogeneous plant community, or as the total number of species in a homogeneous stand of vegetation (Whittaker 1977). In this study the average number of species recorded in the samiple plots representing each plant community, was calculated and species richness is indicated as number of species per $100 \mathrm{~m}^{2}$.

The Simpson and Shannon-Wiener diversity indices were used to combine species richness and evenness (Barbour et al. 1987). Species evenness is defined as the distribution of individuals or the relative abundance among species.

Beta diversity refers to species turnover along an environmental gradient. When presence-absence data are used, as in this study, two measures of beta diversity are recommended by Wilson \& Shmida (1984). The first is that of Whittaker (1960), which is determined from the total number of species recorded in the study system divided by the average number of species found within the community samples, and the second that of Wilson \& Shmida (1984) which is calculated from the mean sample richness and the number of species gained and lost along the environmental gradient.

\section{Results}

\section{Classification}

The vegetation of the WNR can be divided into eleven piant communities, two of which can be subdivided (Table 1). These are grouped under four major types, namely grassland, woodland, disturbed vegetation and wetlands.

\section{A. Grassland}

1. Myrothamnus flabellifolius - Ursinia nana Herbland

2. Themeda triandra - Eragrostis racemosa Grassland

2.1 Themeda triandra - Elephantorrhiza elephantina Grassland

2.2 Themeda triandra-Nidorella hottentottica Grassland

3. Themeda triandra-Mundulea sericea Open Shrubland 
4. Berkheya insignis - Diheteropogon amplectens Grassland

B. Woodland

5. Rhus leptodictya - Grewia occidentalis Woodland

5.1 Acacia karroo - Eragrostis chloromelas Open Woodland

5.2 Acacia caffra-Eragrostis chloromelas Open Woodland

5.3 Acacia caffra - Pavetta gardeniifolia Closed Woodland

C. Disturbed vegetation

6. Melinis repens - Eragrostis chloromelas Disturbed Grassland

7. Hyparrhenia hirta - Stoebe vulgaris Disturbed Grassland

D. Wetlands

8. Eragrostis plana - Andropogon huillense Dry Marshland

9. Echinochloa jubata-Juncus effusus Lake Shore Community

10. Rhus gerrardii - Leersia hexandra Riparian Community

11.Typha capensis - Agrostis lachnantha Marshland

Description and discussion of the plant communities

\section{A. Grassland}

This major vegetation type represents the natural grassland communities on the reserve. These grasslands mostly occur on exposed, high-lying crests in the rolling landscape, mostly on shallow, rocky soils. Grassland communities are characterised by Species Group 8 (Table 1), which includes typical Rocky Highveld Grassland species such as the chamaephyte grasses Diheteropogon amplectens, Tristachya biseriata, Panicum natalensis, Urelytrum agropyroides, Digitaria tricholaenoides and Bewsia biflora, and forbs such as the reptant hemicryptophyte Turbina oblongata and suffrutescent chamaephyte Athrixia elata (Bredenkamp \& Van Rooyen 1996). Herbaceous chamaephyte and hemicryptophyte life forms predominate and Themeda triandra is dominant. An outstanding feature is the generally low presence of therophytes. If present, this life form is mostly represented by exotic weedy species, or occasionally by a few indigenous species of specifically harsh habitats. This Grassland could be named Diheteropogon amplectens - Themeda triandra Grassland

Similar grassland communities were described from regional vegetation studies by Myburgh (1993) in the MiddelburgBelfast area, and by Coetzee et al. (1995a) in the Pretoria-Witbank-Heidelberg area. Related vegetation also occurs on quartzite in the Suikerbosrand Nature Reserve (Bredenkamp \& Theron 1978) and in the Witwatersrand Botanic Garden (Behr \& Bredenkamp 1988), though in these cases obvious differences in geology, with resulting variation in plant communities, are evident.

\section{Myrothamnus flabellifolius - Ursinia nana Herbland}

This community occurs on extremely rocky sites on crests and gentle slopes, where felsite rock sheets have a surface cover of $99 \%$. Diagnostic species are listed under Species Group 1 (Table 1). Many of these species are xerophytic, and restricted to rocky sheets with pockets of very shallow soil, e.g. the poikilohydrous frutescent chamaephyte Myrothamnus flabellifolius, the succulent chamaephytes Crassula setulosa and Anacampseros subnuda, the grasses Aristida junciformis, Microchloa caffra, Sporobolus stapfianus and $S$. discosporus and the hemicrytophyte fern/fern ally Cheilanthes quadripinnata and Selaginella dregei. Most individual plants grow wedged in cracks in the rock sheets, or in the extremely shallow soil $(1-30 \mathrm{~mm})$ that may accumulate locally on the rock sheets. 
This plant community is unique in species composition and shows almost no floristic relationship with the other plant communities in the WNR. However, Microchloa caffra, Laperousia sandersonii, Selaginella dregei, Aristida junciformis and Commelina africana may also occur in rocky areas occupied by other plant communities, especially Communities 2.1, 2.2 and 3 .

Presence in this community of indigenous therophytes, such as Ursinia nana, Monsonia angustifolia and Limeum pauciflorum, may be ascribed to the harsh habitat conditions on the exposed felsite rock sheets, where this life form is considered as a survival strategy. Although most grasses are perennial (Gibbs Russell et al. 1990), they are relatively short with shallow root systems. Sporobolus stapfianus, S. discosporus and Microchloa caffra are typical grasses of shallow or saline soils and rocky habitats (Gibbs Russell et al. 1990). Geophytes, e.g. Lapeirousia sandersonii with corms and Nerine rehmannii with bulbs are, as most other plants in this community, wedged in cracks between the rocks.

\section{Themeda triandra - Eragrostis racemosa Grassland}

This community is regarded as the climax grassland of the area, representing typical Rocky Highveld Grassland (Bredenkamp \& Van Rooyen 1996). It occurs on plateaux and gentle slopes, in the rolling countryside, and is the most typical plant community of the broader Diheteropogon amplectens Themeda triandra Grassland. This grassland is dominated by perennial grasses, mostly representing herbaceous chamaephytes and hemicryptophytes, with suffrutescent chamaephytes and geophytes in smaller numbers. Diagnostic species, given under Species Group 4 (Table 1), include amongst others, typical Rocky Highveld Grassland species such as the grasses Trachypogon spicatus, Schizachyrium sanguineum and Digitaria monodactyla and the hemicryptophytes Pentanisia angustifolia and Justicia anagalloides (Bredenkamp \& Van Rooyen
1996). Species indicating an Afromontane affinity include Monocymbium ceresiiforme. Helichrysum coriaceum, Gnidia sericocephala and Lotononis eriantha.

Two sub-communities are recognised.

Themeda triandra - Elephantorrhiza elephantina Grassland (2.1) is typically associated with shallow, rocky soils (up to $80 \%$ rock cover) on slopes to the east of the Olifants River, and is characterised by the presence of the diagnostic species listed in Species Group 2 (Table 1). Themeda triandra - Nidorella hottentottica Grassland (2.2) occurs on the crests or plateaux areas where soils are somewhat deeper and not as rocky ( $5-20 \%$ rock cover). Diagnostic species are given in Species Group 3 (Table 1).

\section{Themeda triandra - Mundulea sericea Open Shrubland}

This community occurs on very shallow soils with with $60-90 \%$ rock cover, found on hot and dry, very steep west-facing slopes. Diagnostic species are listed in Species Group 5 (Table 1) and include microphanerophytes such as Mundulea sericea, Pavetta zeyheri, Englerophytum magalismontanum and Vangueria infausta. causing the vegetation to be an open shrubland (Edwards 1983). Further floristic relationship to the woodland communities (5.1-5.3) is indicated by Species Groups 10 and 17 (Table 1). However, dominant species in this community consist mainly of chamaephytic grasses, e.g. Themeda triandra. Diheteropogon amplectens, Cymbopogon excavatus, Tristachya biseriata and Loudetia simplex. Chamaephytes, hemicryptophytes and geophytes are predominantly present. which supports the inclusion of this community under the grasslands.

\section{Berkheya insignis - Diheteropogon amplectens Grassland}

This grassland community occurs on moderate to steep north and west facing slopes. Soils are shallow and rocks cover $50-95 \%$ 
of the soil surface. Species listed in Species Group 7 (Table 1) are diagnostic. The vegelation of this community differs from Community 3 by the scarcity of phanerophytes, though small individuals of Diospyros lycioides, Rhus pyroides and Heteromorpha trifoliata may occur scattered in this grassland. Furthermore, Lannea edulis and Rhus discolor have aboveground woody structures not taller than $0.5 \mathrm{~m}$, but with enormous underground woody stems. These plants may be considered as underground trees (White 1976), perhaps best referred to as rhizomatous geoxylic suffrutescent chamaephytes. As is the case with Community 3 , some floristic relationship to the woodland communities is indicated by Species Groups 10 and 17 (Table 1).

\section{B. Woodland}

\section{Rhus leptodictya - Grewia occidentalis Woodland}

Savanna Biome floristic elements occur at sheltered sites in the WNR and is represented by the Rhus leptodyctya - Grewia occidentalis Woodland. Mordelet et al. (1993) described savanna as a vegetation type characterised by the co-occurrence of a continuous herbaceous layer and a more or less discontinuous tree layer. Woodland communities with phanerophytes of Zambezian origin (Bredenkamp \& Van Rooyen 1996), occur as sheltered islands of Temperate Mountain Bushveld (Coetzee et al. 1995b) within the Rocky Highveld Grassland. Many of the woody species in Rocky Highveld Grassland (Bredenkamp \& Van Rooyen 1996), are also diagnostic species of the Rhus leptodyctyaGrewia occidentalis Woodland (Species Groups 15 \& 16, Table 1).

Three sub-communities are recognised.

Acacia karroo - Eragrostis chloromelas Open Woodland (5.1) of disturbed footslopes occurs on sandy soils with little or no surface rock. Acacia karroo is the dominant tree, but most of the phanerophytes of the Rhus leptodyctya - Grewia occidentalis Woodland are also present (Species Groups 15 \& 16, Table 1). Diagnostic species (Species Group 11, Table 1) are, however, either weedy pioneer therophytes (often naturalised exotic) such as Achyranthes aspera, Aristida congesta, Hibiscus microcarpus and Zinnia peruviana, or the early successional phanerophytic or hemicryptophytic lianas, such as Pentarrhinum insipidum and the exotic Araujia sericifera. This sub-community may be regarded as a disturbed variation of Sub-community 5.2.

Acacia caffra - Eragrostis chloromelas Open Woodland (5.2) is dominated by Acacia caffra and A. karroo. Diagnostic species (Species Group 12, Table 1), unlike Community 5.1 , do not include weedy pioneer therophytes, but rather indigenous species typical of undisturbed shady habitats under trees, e.g. the hemicryptophyte Gerbera jamesonii and the geophytes Scadoxus puniceus and Bonatea speciosa. Also present are species typical of grassland communities (Species Groups 9 \& 10, Table 1). The presence of Species Group 13 (Table 1), and especially the dominance of Acacia karroo in both Communities 5.1 and 5.2 further suggests that these two communities may be regarded as an unit.

Acacia caffra - Pavetta gardeniifolia Closed Woodland (5.3) is characterised by the absence of graminoids and is dominated by large phanerophytes, forming a near-forest thicket vegetation.

Diagnostic species (Species Group 14, Table 1) include caespitose microphanerophytes such as Pavetta gardeniifolia, Myrsine africana, Canthium gilfillanii, Diospyros whyteana and Maytenus heterophylla, and scapose microphanerophytes Dovyalis caffra and Zanthoxylum capense. Shade-loving herbaceous chamaephytes such as the pteridophytes Cheilanthes viridis and Ceterach cordatum and the hemicryptophyte Plectranthus grallatus are also diagnostic. Many of these species are of Afromontaneaffinity, indicating that this forest-like community may represent a relict of a former more wide-spread Afromontane vegetation. 







\begin{tabular}{|c|c|c|c|c|}
\hline & & \multicolumn{3}{|l|}{$\sim$} \\
\hline & & \multicolumn{3}{|l|}{-} \\
\hline & & $\sim$ & + & \\
\hline+ & + & & + & ++ \\
\hline
\end{tabular}

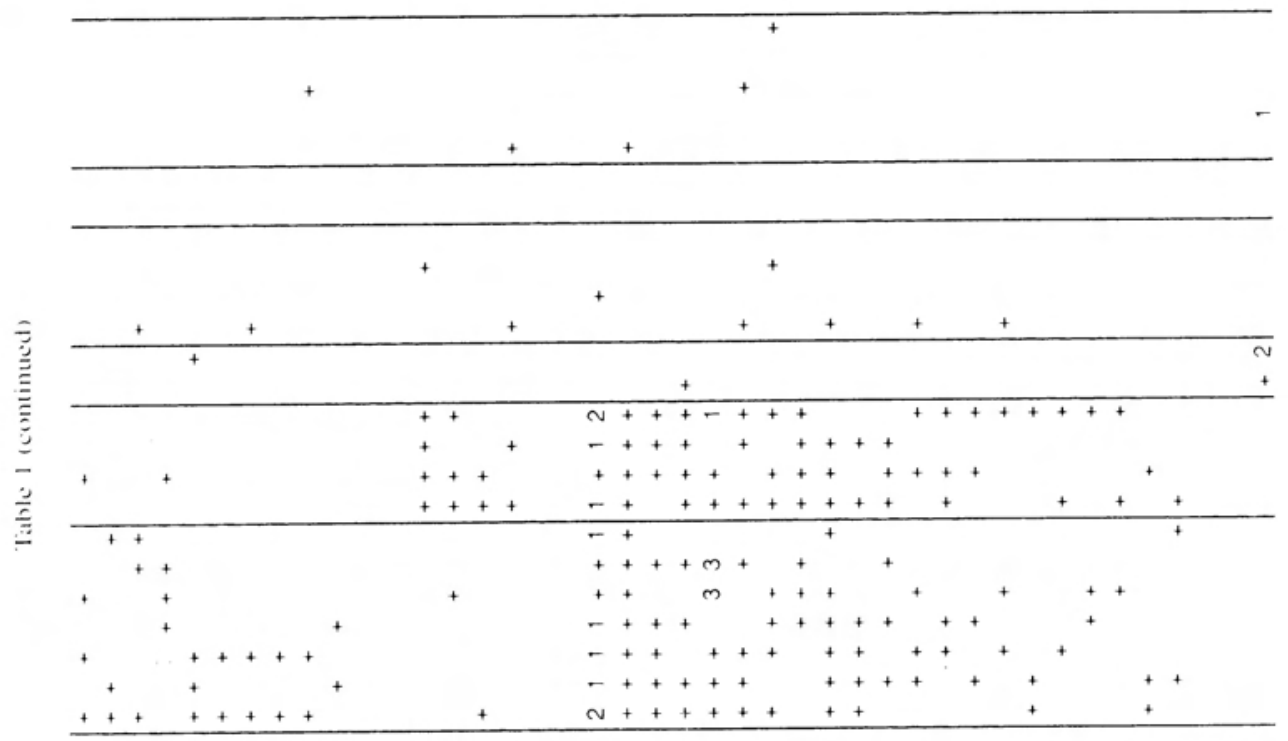

\begin{tabular}{|c|c|c|c|c|}
\hline 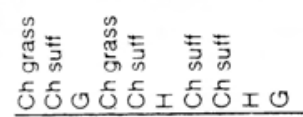 & 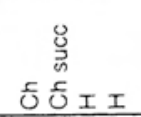 & 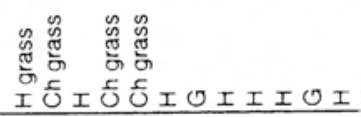 & 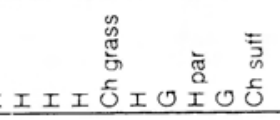 & a \\
\hline
\end{tabular}

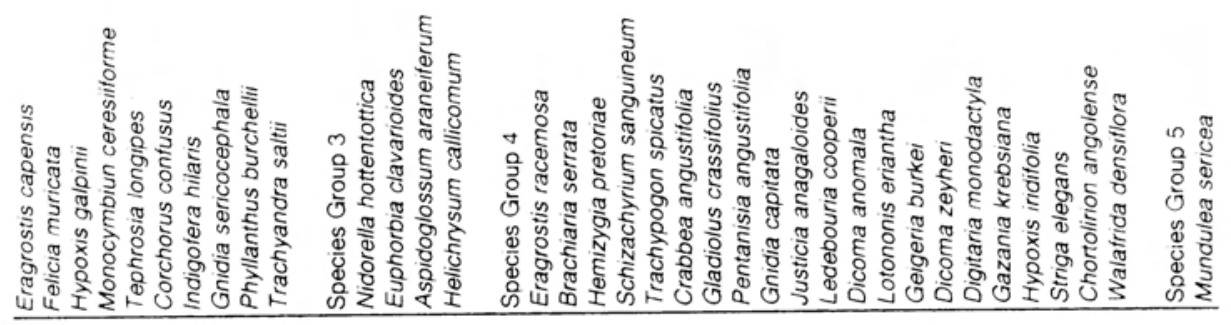




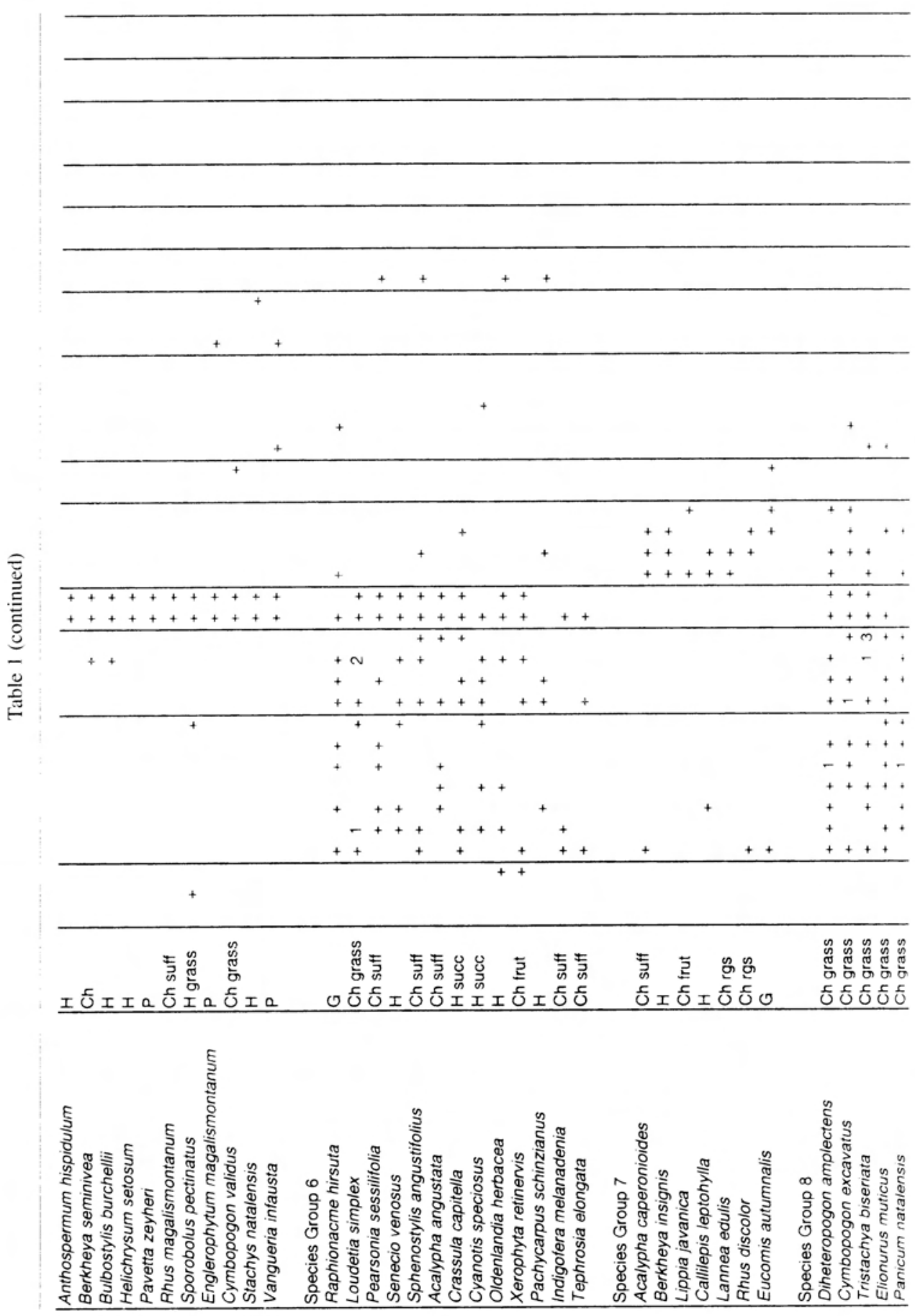




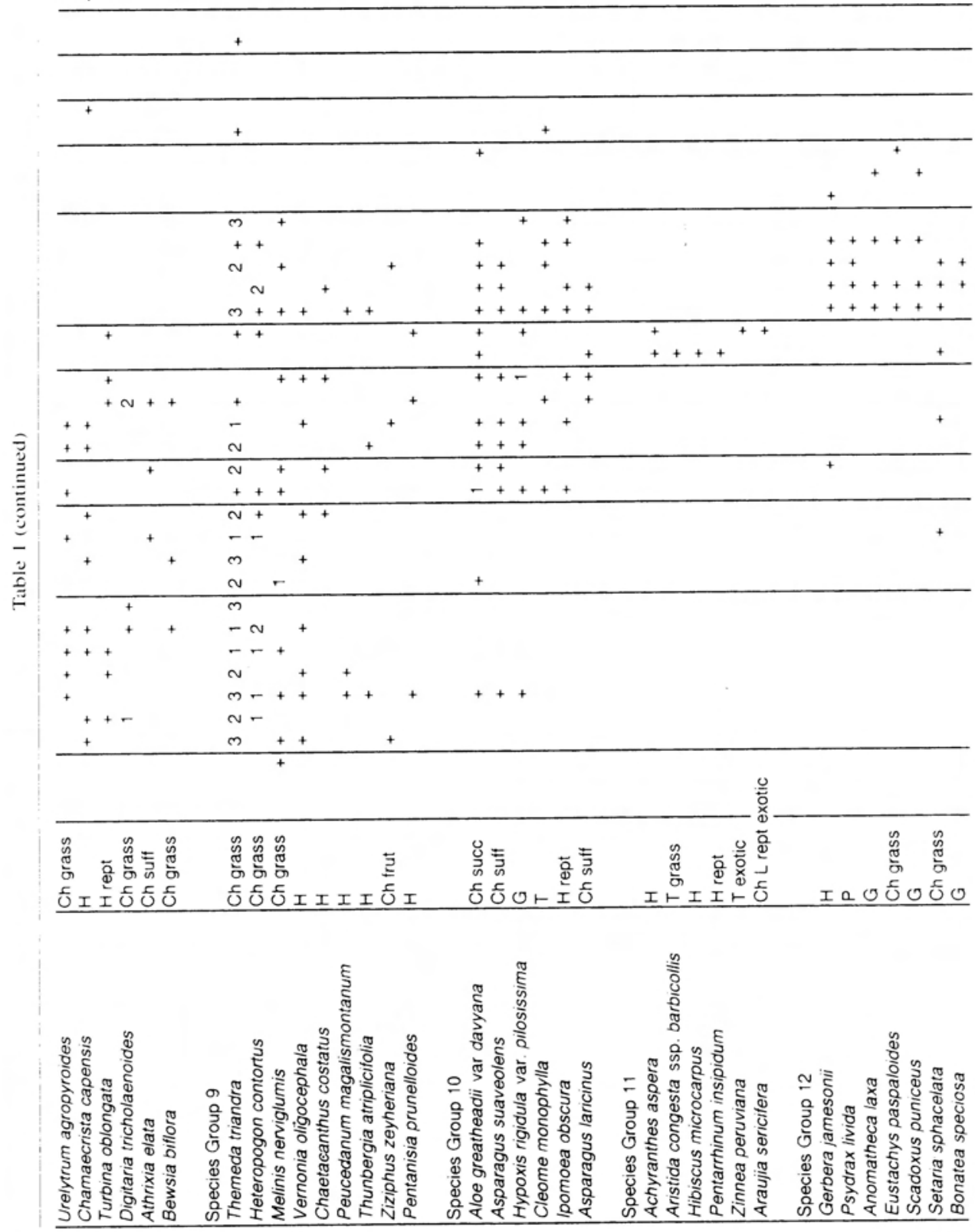




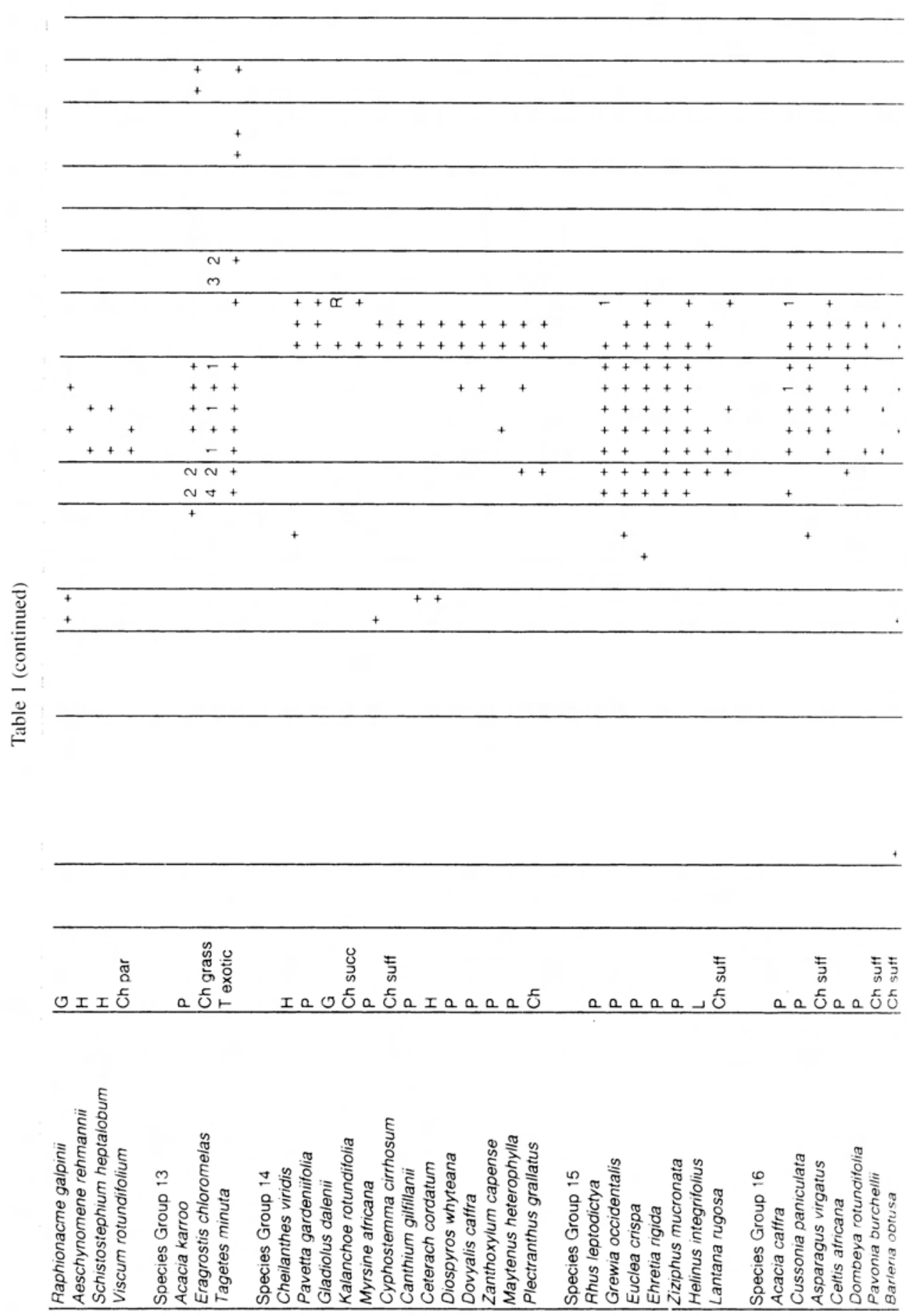




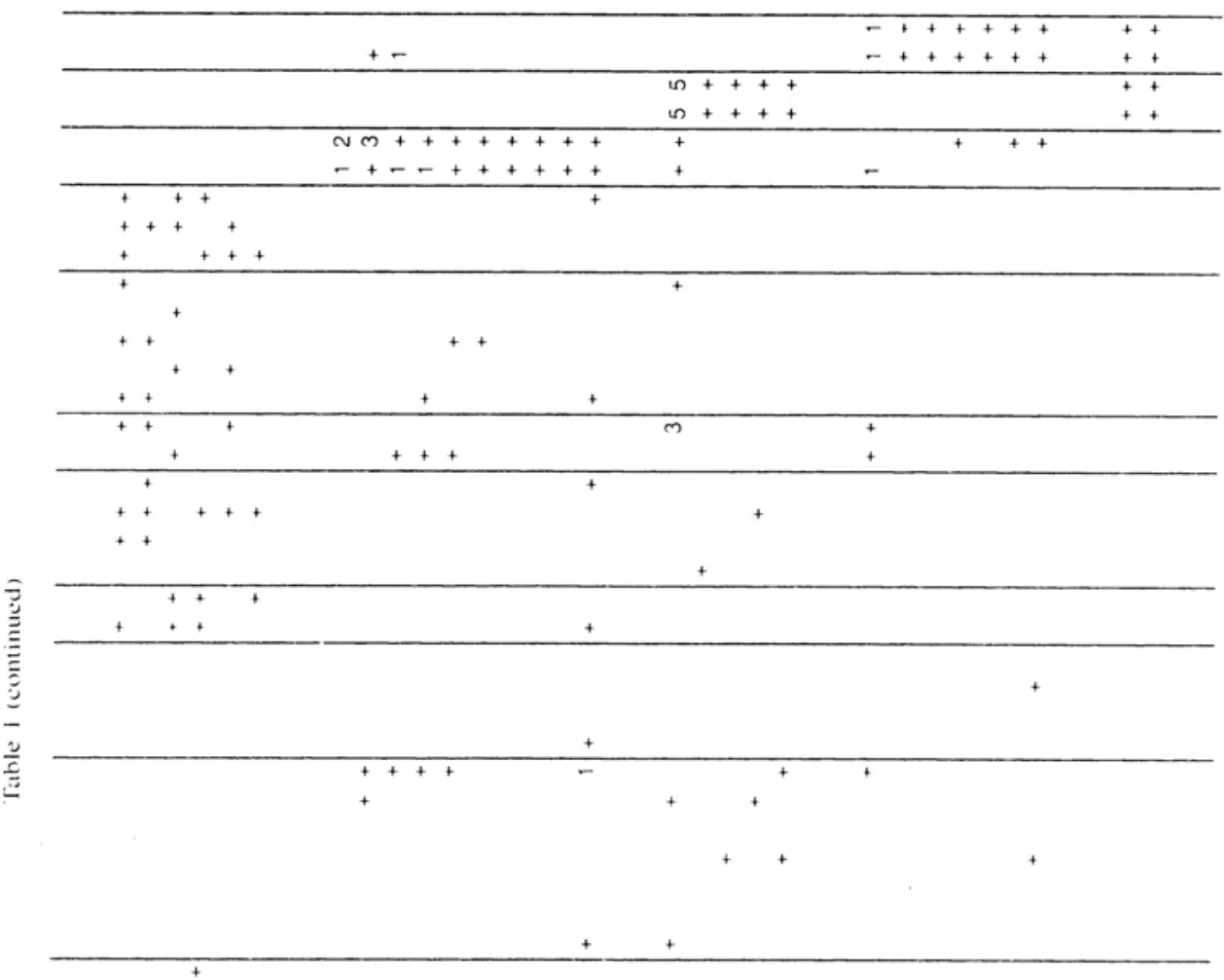

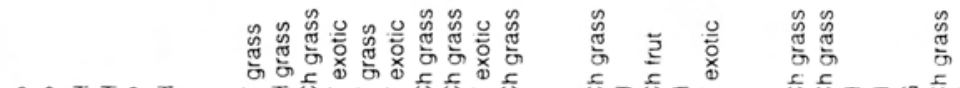

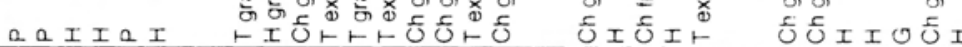
I I

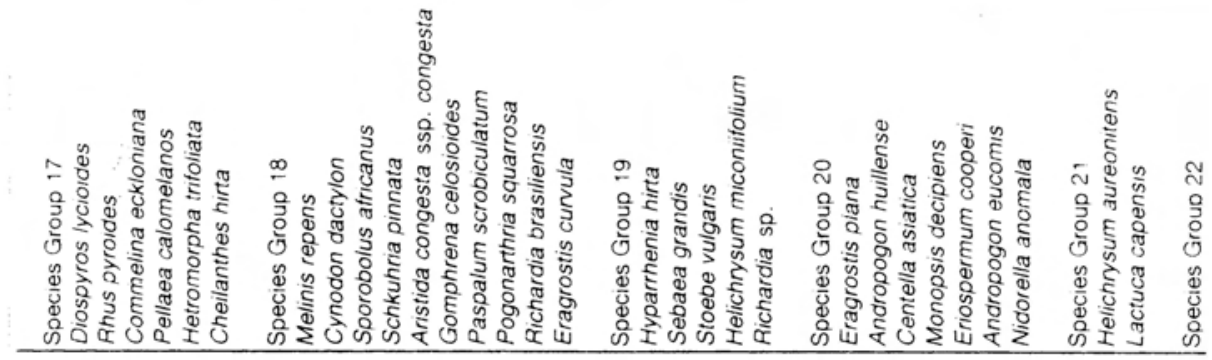




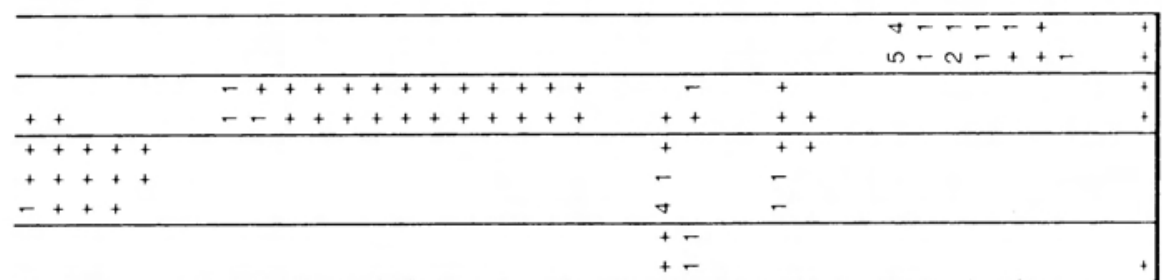

$+$

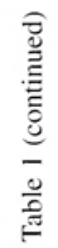

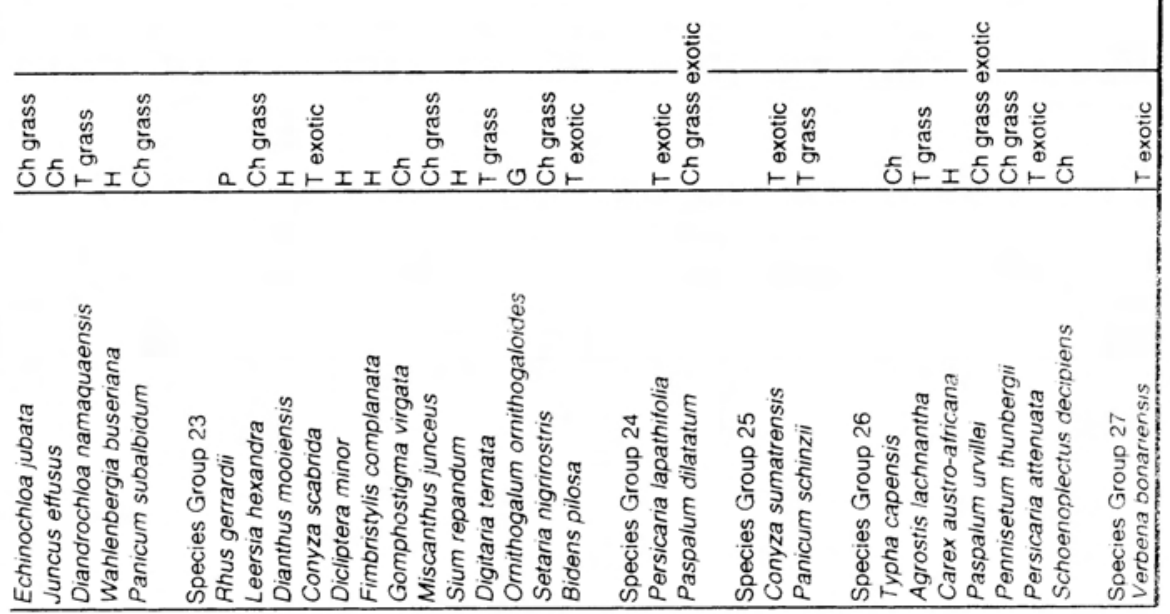




\section{Disturbed Vegetation}

\section{Melinis repens - Eragrostis chloromelas Disturbed Grassland}

This community occurs on almost level sites that were previously cultivated, the Clovelly or Hutton soils being relatively deep ( $>300$ $\mathrm{mm})$, and well drained. Surface rock is absent. Therophytes are abundant in this secondary vegetation, but they are mainly exotic weedy pioneers or pioneer annual grass species. Diagnostic species, listed in Species Group 18 (Table 1), are all annual weeds or perennial pioneer species typical of old cultivated fields. The vegetation is dominated by grasses such as Melinis repens, Cynodon dactylon (Species Group 18) and Eragrostis (hloromelas (Species Group 13). Most notable is the paucity of forbs characteristic of the original Diheteropogon amplectens Themeda triandra Grassiand (Species Groups $2-9$, Table 1), in spite of a recovery period of 17 years.

\section{Hyparrhenia hirta - Stoebe vulgaris Disturbed Grassland}

This community occurs on poorly drained, previously ploughed soils along streambanks. The vegetation is dominated by the tall grass, Hyparrhenia hirta and the diagnostic species are listed in Species Group 17 (Table 1). This grassland vegetation is regarded as secondary. It has been observed in previous studies (Smit 1992), at localities in Kwazulu-Natal and the Free State, that Hyparhenia hirta-dominated secondary grassland resists further succession and very seldom returns to former climax communities. indicating the fragility of South African climax grassiand ecosystems. Observations in other parts of the Rocky Highveld Grassland, e.g. the Suikerbosrand Nature Reserve (Bredenkamp 1975), have shown that floristic impoverishment, concomitant with dominance of Hyparrhenia hirta, is still present in old fields cultivated up to 30 years, and probably much longer ago. Hence ploughing seems to cause almost irreversible destruction of original grassland communi- ties, indicating that South African grassland communities lack the potential to recover after severe disturbance, such as ploughing.

\section{Wetlands}

Wetland communities are characterised by the dominance of hygrophilous plant species. Typically, these communities have a low floristic diversity, but the different wetland communities differ considerably in species composition, with virtually no floristic similarities among the various wetland types recognised. This is in concordance with wetlands in other parts of the Grassland Biome (Bloem et al. 1993, Eckhardt et al. 1993, Smit et al.1995). Four different wetland types are recognised:

\section{Eragrostis plana - Andropogon huil- lense Seasonally Dry Marshland}

This community occurs on seasonally dry marshland areas, situated in non-perennial water courses and drainage lines on southfacing aspects, sloping towards the Dam. Diagnostic species are given in Species Group 20 (Table 1), with the hygrophilous herbaceous chamaephyte grass Eragrostis plana dominant. The presence of naturalised alien species, such as herbaceous chamaephytes Persicaria laphatifolium and Paspalum dilatatum, indicates a mild degree of disturbance.

\section{Echinochloa jubata-Juncus effusus Lake Shore Community}

This community occurs on the rocky and gravelly shores of the lake, a man-made, disturbed habitat. It is characterised by Species Group 22 (Table 1), with the grass Echinochloa jubata and the sedge Juncus effusus most prominent. Disturbance is indicated by the abundance of the weedy, exotic therophyte Conyza sumatrensis (Species group 25) and the herbaceous chamaephyte Persicaria laphatifolia (Species group 24). Due to periodic drought conditions, the 
water level of the lake retreats and these weedy species invade the exposed areas.

\section{Rhus gerrardii - Leersia hexandra Riparian Community}

This community occurs mainly in the rocky stream bed and along the river banks, the rocks mostly being large boulders. Diagnostic species are listed under Species Group 23 (Table 1). Rhus gerrardii is a caespitose nanophanerophyte of Afromontane affinity, which occurs commonly on streambanks in the eastern parts of the Rocky Highveld Grassland. Gomphostigma virgata is a widespread rheophyte throughout the region. The most prominent herbaceous species are the diagnostic grasses Miscanthus junceus, a tall growing graminoid and the reptant Leersia hexandra.

\section{Typha capensis-Agrostis lachnanta Marshland}

This community occurs on the permanently wet soil on the banks along slow flowing parts of the streams. Diagnostic species are given under Species Group 26 (Table 1). The vegetation is entirely dominated by the graminoid Typha capensis, with Agrostis lachnantha, Carex austro - africana and Paspalum urvillei also prominently present. All species recorded in this community are strongly hygrophilous, growing in or close to the water.

\section{Ordination}

The distribution of the plant communities of the WNR along the first and second axes of the DECORANA ordination is shown in Fig. 2. Soil moisture increases from left to right on axis 1. The first axis (eigen value 0.938) explains most of the variation in the data, indicating the importance of the soil moisture gradient in interpreting the environment of the vegetation of the WNR. Grassland communities (1, 2.1, 2.2, 3 \& 4) are located on the extreme left of the diagram, followed further to the right by the closed woodland, forest-like community (5.3), then the open woodlands ( $5.2 \& 5.1)$.

Disturbed communities (6 \& 7) are located in the centre of the diagram. Hygrophilous communities (8-11) on the right reflect an increase in soil moisture from 8 and 9 through 10 to 11 . Community 11 is situated in extreme wet conditions.

The environmental gradient along axis 2. which has an eigen value of 0.734 , is not so clear, though may be associated with soil depth or surface rockiness. Rockiness increases from bottom to the top, with an associated decrease in soil depth. Community 1 , located on the top left, is situated in extremely rocky conditions (99\% surface rocks), whereas the woodlands (5.1-5.3) also occur on shallow, rocky soils.

Grasslands (2.1 \& 2.2), located at the bottom left, indicate relatively deeper soils, but the deepest, non-rocky soils are found in the disturbed communities ( $6 \&$ \& ), not clearly explained by the ordination.

\section{Phytodiversity}

Graphic presentations are given of Averagc Species Richness (Fig. 3), Simpson's Index (Fig. 4), Shannon-Wiener Diversity Index (Fig. 5), Whittaker's Beta Diversity Index (Fig. 6) and Wilson \& Shmida's Beta Diversity Index (Fig. 7) for the plant communities in the WNR. In all these Figures. the sequence of the plant communities is that obtained from the first axis of ordination (Fig. 2).

\section{Alpha diversity}

The undisturbed grassland communities $(2.1,2.2,3)$ have the highest species richness (Fig. $3 \& 5$ ), followed by the woodlands (Communities 5.1, 5.2. 5.3). The diturbed secondary grasslands of previousl! cultivated areas, Community 6 and especia!ly Community 7 and the wetland communi. ties $(8,9,11)$, have a low species richness. Most wetland communities are dominated by one or a few species, which contribute to lower diversity indices, as the Shannon- 


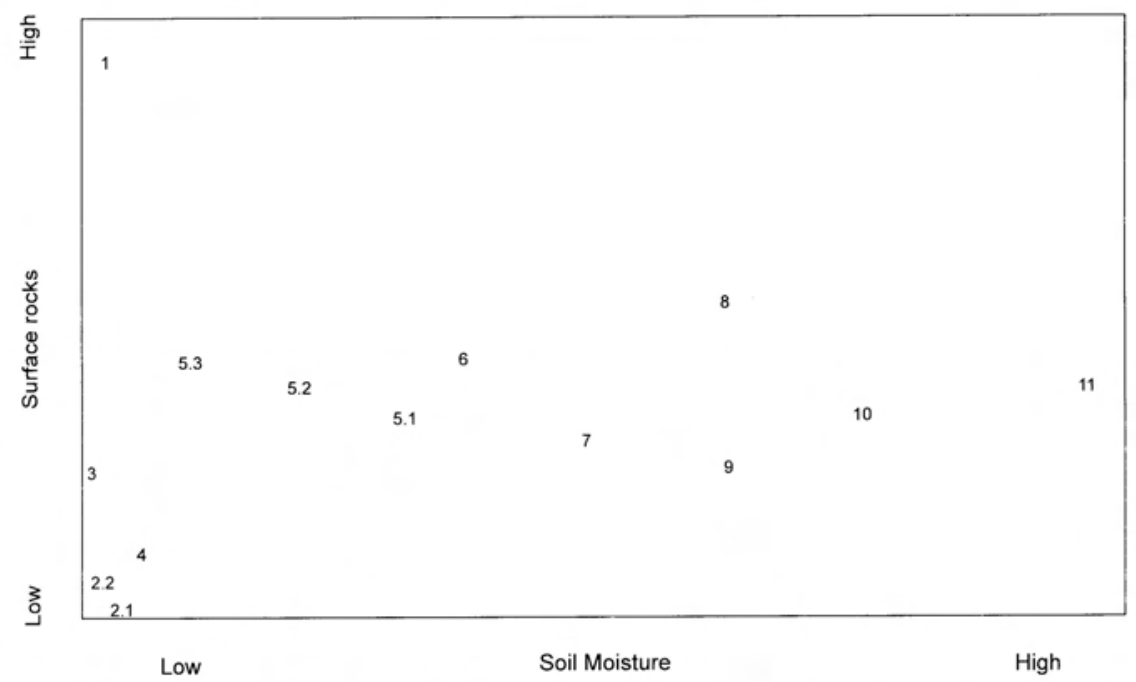

Fig. 2. Distribution of the plant communities along the first and second axes of a Decorana ordination. Plant community numbers as in the text.

Wiener Diversity Index weights dominant species down. This phenomenon is clearly illustrated in the species poor, disturbed grassland Community 7 , which is dominated by the tall grass Hyparrhenia hirta. This community has the second lowest Average Species Richness (Fig. 3) and the lowest Shannon-Wiener Index (Fig. 5).

Grassland Community 3 has the highest Average Species Richness (Fig. 3), as well ats the highest Shannon-Wiener index (Fig. 5). This grassland community occurs on very

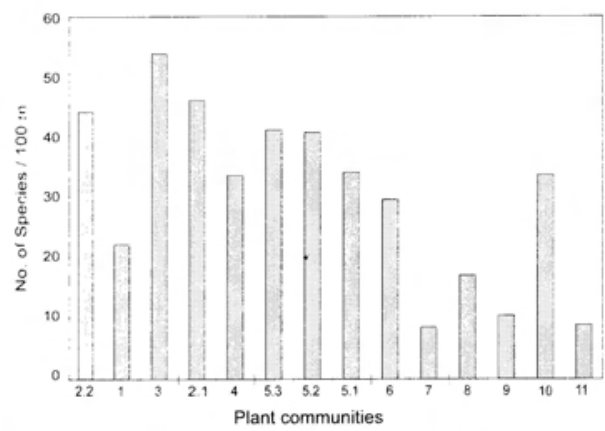

Fig. 3. Average species richness of the plant communities in the Witbank Nature Reserve. rocky, warm western slopes, with grassland as well as bushveld elements, and a lack of dominance by a single or a few species. Results from Simpson's Index emphasise the low diversity of communities 7 and 11 Fig. 4), but these results are generally not as informative as Average Species Richness and the Shanon-Wiener Index.

Beta diversity

Species turnover along the environmental gradient, as indicated by the ordination (Fig.

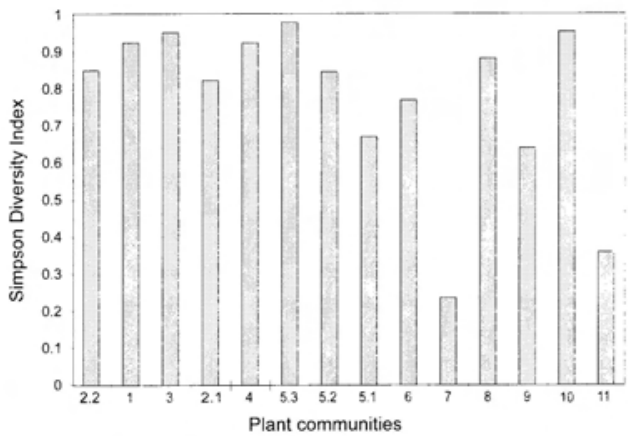

Fig. 4. Simpson's Dominance Indices of the plant communities in the Witbank Nature Reserve. 


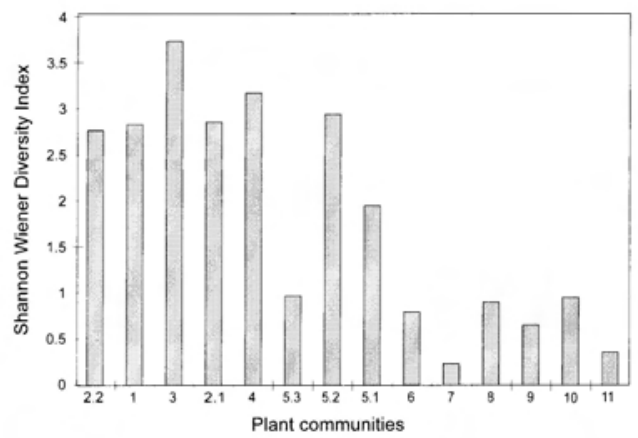

Fig. 5. Shannon-Wiener Diversity Indices of the plant communities in the Witbank Nature Reserve.

2), has been determined. According to Whittaker's Beta Diversity Index (Fig. 6), Community 2.1 has the highest beta diversity. Wilson \& Shmida's (1984) Beta Diversity Index (Fig. 7) shows that the highest species turnover was between Community 4 (grassland) and Community 5.3 (closed woodland). The lowest relative species turnover was among the wetland communities (8-11).

\section{Discussion}

Although the WNR is relatively small, its heterogeneous topography and consequently large variety of habitats and niches, result in a considerable richness of plant species. Not only is the Reserve situated in the transitional zone between the Rocky Highveld Grassland and the Moist Sandy Highveld Grassland, but the ecotonal location between typical Grassland and Savanna Biome vegetation types, together with a distinct Afromontane affinity (Coetzee et al. 1995b), as seen in both grassland species and forestlike vegetation, confers on the Reserve an unique conservation status.

The question arises as to whether it is a viable option to preserve such a relatively small area, and whether its constituent plant communities stand a chance to survive and maintain their present biodiversity. Franklin (1993) referred to the importance of the

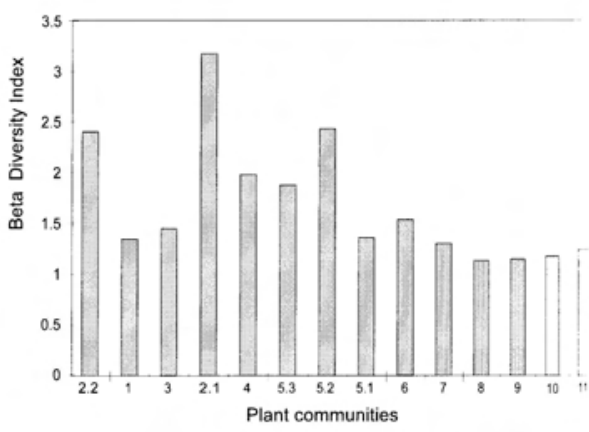

Fig. 6. Beta Diversity Indices (Whittaker 1960) of the plant communities in the Witbank Naturc Reserve.

"unreserved matrix" in which a reserve is embedded. He emphasised the importance of recognising the extensiveness of edgeeffects. The higher the contrast between two patch types, e.g. between a reserve and its unreserved surroundings, the greater the edge-effect. To reduce this edge-influence. the matrix should provide connectivity in the landscape, especially connectivity between reserves (Franklin 1993). A different viewpoint is to see a reserve as an island. surrounded by a "sea" of pastures, cultivated fields, urban development and industries. which isolates the "island" from comparable habitats (Bond 1993). It is expected that an isolated area (island) will experience a loss

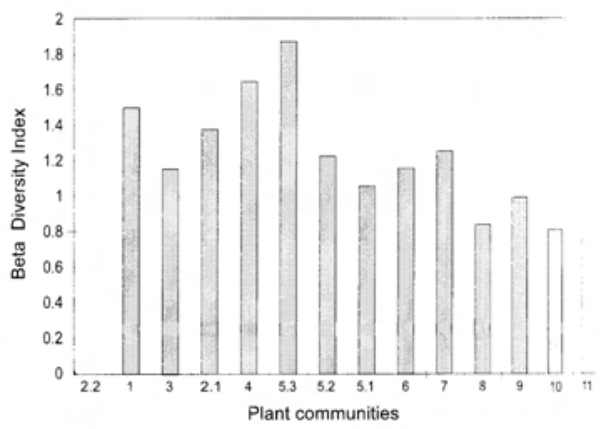

Fig. 7. Beta Diversity Indices (Wilson \& Shmidia 1984) of the plant communities in the Witbank Nature Reserve 
of species, and the magnitude of this loss will be directly related to the size of the island (Bond 1993). The smaller the island, the greater the loss of species. However, assessing the immediate surrounding land forms with its mining activities, urban development and agriculture, it is obvious that the specific topography and land form found in the WNR, must have already existed as an isolated island of Rocky Highveld Grassland in Moist Sandy Highveld Grassland for a considerable length of time, probably many thousands of years. The mosaic of various plant communities of different origin and affinity is normal in the Rocky Highveld Grassland, a transitional zone between the high altitude, cool, moist Grassland Biome and the warmer, lower altitude Savanna Biome. Afromontane species occur only locally, where conditions are favourable, thus reflecting a further transitional tract linked to the Afromontane vegetation of the Great Escarpment. It is clear that the small island of plant communities in the WNR must have existed, survived and maintained itself in this area for many centuries. The conservation of a relatively small nature reserve under these circumstances is therefore not only viable, but also essential, to preserve vegetation types and plant species with affinities to three major ecosystems (Grassland, Savanna, Afromontane) in a natural island situation.

All the above arguments should, however, be kept in mind when managing such a small nature reserve. A solution to the problem of particularly zoological impoverishment may be the maintainance of corridors of natural vegetation. In Australia retained systems of linear habitat or wildlife corridors are widely used in temperate wood-producing forests (Lindenmayer 1994). The main role of these corridors are to allow the movement of animals between reserved areas. Although such corridors may also provide for the migration of plant species, such role is of doubtful significance. Undisturbed mesophytic Highveld grassland communities are extremely stable ecosystems, with particularly non-grassy forbs living to a great age. Seed generation and species turnover appear to be low. This great stability is reflected by the apparent inability of severely disturbed areas to regain their original levels of floristic diversity, despite being surrounded by undisturbed species-rich areas.

Some actions could, however, improve the viability of the WNR further, e.g. an increase in the size of the Reserve and especially the participation of neighbouring farmers in conserving areas of natural vegetation on their land, perhaps by establishing a conservancy. Of great importance is the introduction of an ecologically based veld and wildlife management programme to ensure correct stocking rates for game, protection of sensitive ecosystems and the application of a fire management programme.

\section{References}

ACOCKS, J.P.H. 1988. Veld types of South Africa. Memoirs of the Botanical Survey of South Africa 57: 1-146.

ARNOLD, T.H. \& B.C. DE WET. 1993. Plants of southern Africa: names and distribution. Pretoria: National Botanical Institute.

BARbour, M.G., J.H. BURK \& W.D. PITTS. 1987. Terrestrial Plant Ecology. Menlo Park, California: Cummings.

BEHR, C.M. \& G.J. BREDENKAMP. 1988. A phytosociological classification of the Witwatersrand National Botanic Garden. South African Journal of Botany 54: 525-533.

BLOEM. K.J., G.K. THERON \& N. VAN ROOYEN. 1993. Wetland plant communities of the Veriorenvalei Nature Reserve in the North-eastern Sandy Highveld, Transvaal. South African Journal of Botany 59: 281-286.

BOND, W.J. 1993. Describing and conserving biotic diversity. Pp. 2-18. In: HuntLEY, B.J. (ed.). Biotic diversity in southern Africa: concepts and conservation. Cape Town: Oxford University Press.

BREDENKAMP. G.J. 1975. 'n Plantsosiologiese studie van die Suikerbosrandnatuurreservaat. M.Sc. Thesis. University of Pretoria, Pretoria.

BREDENKAMP. G.J. 1982. 'n Plantekologiese studie van die Manyeleti Wildtuin. D.Sc. Thesis. University of Pretoria. Pretoria.

BREDENKAMP. G.J. \& G.K. THERON. 1978. A synecological account of the Suikerbosrand Nature Reserve. I. The phytosociology of the 
Witwatersrand geological system. Bothalia 12: 513-529.

BREDENKAMP, G.J. \& N. VAN ROOYEN. 1996. Rocky Highveld Grassland. Pp. 39. In: Low, A.B. \& A.G. REBELO (eds.). Vegetation of South Africa, Lesotho and Swaziland. Pretoria: Department of Environmental Affairs and Tourism.

CoetzeE, J.P., G.J. BREDENKAMP \& N. VAN ROOYEN. 1995a. The phytosociology of the grasslands if the $\mathrm{Ba}$ and $\mathrm{Ib}$ land types in the Pretoria-Witbank-Heidelberg area. South African Journal of Botany 61: 123-133.

CoetzeE, J.P., G.J. BREDENKAMP \& N. VAN ROOYEN. 1995b. Plant communities of the Subhumid Cool Temperate Mountain Bushveld in the Pretoria-Witbank-Heidelberg area. South African Journal of Botany 61: 114-122.

ECKHARDT, H.C., N. VAN ROOYEN \& G.J. BREDENKAMP. 1993. Wetland communities of the Vrede-Memel-Warden area, north-eastern Orange Free State. Navorsinge van die Nasionale Museum, Bloemfontein 9: 245-262.

EDWARDS, D. 1983. A broad-scale classification of vegetation for practical purposes. Bothalia 14(3 \& 4): 705-712.

FRANKLIN, J.F. 1993. Preserving Biodiversity: Species, Ecosystyms or Landscapes. Ecological Applications 3(2): 202-205.

Gibbs Russel, G.E., L. Watson, M. Koekemoer, L. SMOOK, N.P. BARKER, H.M. ANDERON, \& M.J. DALLWITZ. 1990. Grasses of Southern Africa. Memoirs of the botanical Survey of South Africa 58: 1-437.

GRONDKLASSIFIKASIEWERKGROEP 1991. Grondklassifikasie-'n taksonomiese sisteem vir SuidAfrika. Memoirs oor die Natuurlike Landbouhulpbronne van Suid-Afrika 15: 1-262.

HILL, M.O. 1979a. TWINSPAN - A FORTRAN program for arranging multivariate data in an ordered two-way table by classification of individuals and attributes. New York: Cornell.

HILl, M.O. 1979b. DECORANA - A FORTRAN program for detrended correspondence analysis and reciprocal averaging. New York: Cornell.

LAND TYPE SURVEY STAFF, 1987. Land types of the maps 2526 Rustenburg and 2528 Pretoria.
Memoirs of the Agricultural Natatural Resources of South Africa No.8.

LINDENMAYER, D.B. 1994. Wildlife Corridors and the Mitigation of Logging Impacts on Fauna in Wood-production Forests in South-eastern Australia: a Review. Wildlife Research 21: 1-19.

LOW, A.B. \& A.G. REBELO (eds.). 1996. Vegetation of South Africa, Lesotho and Swaziland. Pretoria: Department of Environmental Affairs and Tourism.

Mordelet, P., L. AbBadie, \& J-C. Menaut. 1993 Effects of tree clumps on soil characteristics in a humid savanna of West Africa (Lamto, Côte d'Ivoire). Plant and Soil 153: 103-111.

Mueller-Dombois, D. \& H. EllenberG. 1974 Aims and methods of vegetation ecology. Wile!. New York.

MYBURGH, W.J. 1993. Die fitososiologie van dic suurgrasveld in die suidoos-Transvaals Hoëveld. M.Sc. thesis, University of Pretoria. Pretoria.

RAND MINES, 1992. Geological map of the Witbanh Nature Reserve. (Unpublished).

SMIT, C.M. 1992. Phytosociology of the NewcastleMemel-Chelmsford Dam area. M.Sc. thesis. University of Pretoria, Pretoria.

SMIT, C.M., G.J. BREDENKAMP \& N. VAN ROOYFI 1995. The vegetation of the upper Klip River valley in the north-eastern Orange Free State. Navorsinge van die Nasionale Museum. Bloemfontein 11: 38-58.

WesthofF, V \& E. VAN DER MAarel. 1982. The Braun-Blanquet Approach. Pp. 287-399. In: Whittaker, R.H. (ed.). Classification of Plant Communities. The Hague: Junk.

WHITE, F. 1976. The underground forests of Africa: a preliminary review. The Gardens Bulletin (Singapore): 29: 55-71.

WHITTAKER, R.H. 1960. Vegetation of the Siskiyou Mountains, Oregon and California. Ecological Monographs 30: 279-338.

WHITTAKER, R.H. 1977. Evolution of species diversity in land communities. Evolutionary Biology 10: 1-67.

WILSON, M.V. \& A. SHMIDA. 1984. Measuring betil diversity with presence-absence data. Journal of Ecology 70: 1055-1064. 